\title{
Extraterritorial human rights obligations and responsibility under international law ${ }^{1}$
}

\author{
Gamze Erdem Türkelli
}

\section{International law on responsibility and ETOs: The state of the art}

Extraterritorial human rights obligations (ETOs) pose important challenges in the current framework of public international law (IL) as regards how responsibility for internationally wrongful acts ought to be attributed and distributed, especially in cases where the obligations breached are shared by different types of actors. The responsibility of extraterritorial states for human rights violations may take on three forms: 1. responsibility for their own acts or omissions resulting in human rights violations, including the acts of state agents, or a failure to abide by their global obligations; 2 . human rights violations originating from the acts or omissions of international organisations (IOs) to which they are members; 3. Finally, when any entity, such as a business enterprise, that they have obligations to regulate engage in acts or omissions resulting in human rights violations. In many of these cases, the human rights violations in question involve one or more states and one or more types of non-state actors (NSAs). Such scenarios necessitate the consideration of shared responsibility, firstly through the attribution of responsibility to multiple duty-bearers and consequently, the distribution of responsibility among these duty-bearers. The parameters of shared responsibility, particularly when they involve situations of multiple duty-bearing, involving not only states but also IOs and NSAs remain contentious. This chapter first takes stock of the law on responsibility in the context of ETOs, particularly in relation to state responsibility, the responsibility of IOs and shared responsibility. The chapter then provides a critique of existing legal constructs around responsibility with respect to ETOs, identifying gaps. The chapter finally offers alternative sociological and political conceptualisations of shared responsibility.

\section{Basic tenets of the law on responsibility: Attribution of conduct, wrongfulness and enforcement}

Any normative discussion on responsibility for breaches of ETOs needs to start with an assessment of the law on state responsibility, which relates to secondary norms as to outcomes when primary norms (rights and obligations for participants in IL) are violated. The law on responsibility, therefore, responds to the need to enforce these secondary norms when actors 
breach primary norms and relies on the articulation of state responsibility, through the Articles on State Responsibility for Internationally Wrongful Acts (ARSIWA) and the responsibility of IOs through the Articles of Responsibility of International Organisations (ARIO) of the International Law Commission (ILC). According to Art. 2 ARSIWA and Art. 4 ARIO, responsibility is engaged for any action or omission attributable to a state or IO that is in breach of any international obligation, as defined by IL, undertaken by that given state or IO (ILC 2001; ILC 2011a). Law on responsibility is thus not specifically a responsibility regime for human rights violations.

The enforcement of responsibility for internationally wrongful acts begins with the attribution of the conduct (action or omission) to a state or an IO. State responsibility is engaged, according to ARSIWA, when the conduct can be attributed to state organs (art. 4), 'persons or entities exercising elements of governmental authority' (art. 5), organs of third states at the disposal of the said state (art. 6) even if those organs, persons or entities are acting in contravention of instructions or excess of the authority they possess (art. 7) as well as the conduct of person(s) that act on the instructions, direction or control of the state (art. 8), or conduct acknowledged by the state as its own (art. 11). In relevant situations, acts of actors exercising governmental authority or elements thereof (art. 9), or the conduct of insurrections that later become governments (art. 10) are attributed to that state under IL. According to art. 1.2 ARIO, states may additionally incur responsibility for 'internationally wrongful act[s] in connection with the conduct of an international organisation' (ILC 2011a).

The wrongfulness of conduct is gauged when the said conduct is 'not in conformity with what is required' of the state by the obligation (art. 12), in so far as the state is bound by that international obligation at the time of the conduct (art. 13) (ILC 2001).According to ARSIWA, responsibility is triggered by the act of the breach of obligation even if the effects continue over time (art. 14.1), except when the act causing violations (breaches of obligations) has a continuing character (art. 14.2). According to ARSIWA, wrongfulness may be precluded by valid consent, lawful self-defence, countermeasures, force majeure, distress, necessity and compliance with an obligation arising from jus cogens (arts. 20-24). Of course, state responsibility is also engaged when a state is in serious, meaning gross or systematic, breach of peremptory norms of IL (arts. 40-41).

The current articulations of the law on responsibility also extend to 'aid or assistance', or what may be more broadly referred to as complicity, by attributing responsibility to a state or IO when they aid or assist in committing the internationally wrongful act 'with the knowledge of the circumstances' of that wrongful act, and when that act would have been unlawful if committed by itself (ILC 2001, art. 16; ILC 2011a, art. 14). In its Bosnia and Herzegovina v. Serbia and Montenegro judgment, the IJC noted that Art. 16 ARSIWA on aid and assistance reflected the customary IL on state responsibility for complicity (ICJ 2007). Of course, what the ICJ reaffirmed was the existence of such a customary principle but not what that principle required in terms of attribution (Lanovoy 2016). State complicity does not need to be limited to the ARSIWA definition, for instance when it is based on specialised regimes under IL such as Art. 3(e) of the Genocide Convention (Aust 2011). In addition, Aust (2011) posits that obligations on state conduct that can be likened to complicity (such as the non-refoulement obligation under international refugee legal regimes), or positive obligations under human rights conventions may give rise to complicity considerations.

According to ARSIWA, the consequences arising from a state being attributed responsibility for an internationally wrongful act include cessation and non-repetition (art. 30) and reparation (art. 31), which may include restitution - re-establishing the situation before the breach (art. 35), compensation - for all losses (art. 36) or satisfaction when restitution and compensation are 
not possible, including through acknowledging the violation, issuing a statement of regret or a formal apology (art. 37).

\section{Gaps and critiques}

ARSWIA and ARIO, as general public IL frameworks on responsibility, are not sufficient to address human rights responsibility. For instance, their primary limitation is the focus on strict causality, through a fixation on conduct as a single act or omission that triggers a breach. Gauged against real-world human rights violations, strict causality focuses only on one very small part of the overall picture. Often, it is difficult to make the single and strict causal connection between the victim of a human rights violation and the abuser. For instance, 'a single event [could] generate multiple violations by a range of actors' (Clapham 2010, p. 56). In addition, violations of economic, social and cultural (ESC) rights may entail the compounded effect of a number of different acts or omissions, possibly by different duty-bearers. For instance, when states or IOs impose austerity measures or structural adjustment plans on a third state, underfunded health or education systems in the third state that violate human rights will not be readily attributable to a single causal act. Of course, the limitations of strict causality are a relevant consideration for all human rights, not only for ESC rights. The Inter-American Court of Human Rights (IACtHR) held in Velásquez-Rodríguez v. Honduras that states may be held legally responsible for human rights violations resulting from the acts of private or unknown actors if they fail their duty of due diligence to prevent the violation (IACtHR 1988). More recently, in Munaf v. Romania, the UN Human Rights Committee noted that states may be held responsible for violations of the International Covenant on Civil and Political Rights (ICCPR) beyond their borders if they are 'a link in the causal chain' that enables said violations in another state when the risk of violations is a result of the 'necessary and foreseeable' result of their conduct (UN HR Committee 2009). Law on responsibility, if it is to have relevance in the human rights arena, needs to become 'relevant to the nature of contemporary human rights violations' (Salomon 2007, p. 182).

Another important shortcoming of the existing frameworks on responsibility is linked to the limited purview they accord for the existence of multiple duty-bearers to be addressed in relation to a violation. ARSIWA and ARIO recognise that several states and IOs can jointly be responsible for a wrongdoing if they are both bound by the international obligation in question, and if they can both be attributed the conduct leading to the wrongdoing. Beyond the considerations of 'aid or assistance', the frameworks are unable to resolve issues of legal responsibility involving multiple duty-bearers that are not states or IOs (Nollkaemper and Plakokefalos 2016). Independent responsibility, on which current international law is based, arises when responsibility for a wrongdoing is attributed to each duty-bearer independently of other duty-bearers and exclusively (Nollkaemper and Jacobs 2013). Beyond independent responsibility, violations by a multiplicity of actors can amount to responsibility for collective and concerted action as well as responsibility where different actors contribute to a harm with individual actions but not in any collective or concerted way, which requires apportioning responsibility.

\section{Responsibility for violations of ETOs: Beyond the ILC's articles}

Responsibility for ETOs necessitates moving beyond conceptualising violations as strict causation. A state's responsibility for ETOs should be considered in relation to at least three situations: first, for its own acts or omissions giving rise to the violations of its ETOs; second, for the conduct of IOs to which it is a member; third, for the conduct of another entity, such as an NSA. 


\section{State responsibility for its own acts or omissions in breach of ETOs}

The practical implementation of state responsibility for human rights violations under IL through courts has largely rested on a territorial model of attributing obligations, with exceptions made for effective control over territory, persons or situation (Milanovic 2011). The European Court of Human Rights (ECtHR), for instance, has consistently applied this territorial model, where the domestic state is considered the primary and often sole duty-bearer in relation to human rights on its territory, with exceptions for effective control over territory (ECtHR 1996; ECtHR 2011b) or over persons (ECtHR 2011a; ECtHR 2014a). In these exceptional circumstances, State B replaces State A as the duty-bearer and breaching these duties is then the basis for the attribution of responsibility to that state. The Inter-American Commission on Human Rights (IACmHR 2002) has considered states' human rights obligations not to be constrained by the territory they control but as extending to all persons over whom the state has 'authority and control' (para. 44), giving rise to responsibility if these are breached.

The ECtHR has also dealt with cases where a state does not have complete control over its internationally recognised territory. In the cases on Transnistria (Ilaşcu, Catan and Mozer) the ECtHR found that, both Moldova that did not have effective control in the area and Russia that aided and assisted the self-proclaimed Moldavian Republic of Transnistria had breached their obligations and bore responsibility for the human rights violations in question. Moldova was only considered to have limited positive obligations to 'take the diplomatic, economic, judicial or other measures that it is in its power to take and are in accordance with international law' (2004, paras. 330-331) and only attributed responsibility if that positive obligation was not discharged, whereas Russia was found to be exercising jurisdiction and therefore attributed responsibility over the specific violations in question. The issue of the attribution of responsibility to multiple states also arose in Jaloud v. the Netherlands, where the ECtHR noted, in addition to the Netherlands having jurisdiction over Mr Jaloud who had been shot and killed by a Dutch military personnel, that the UK which controlled the part of Iraq where the events occurred could have 'concurrent jurisdiction' (ECtHR 2014b, para. 153). The joint responsibility of the Netherlands and the UK was not invoked by the Court since the UK was not a respondent state in the case.Yet, from a conceptual perspective, if concurrent jurisdiction by more than one state is found to exist over a situation that entails the same human rights obligation, the breach of the obligation could give rise to responsibility of each of these states.

In contrast, the scope of state responsibility under the Maastricht Principles covers all conduct violating its human rights obligations 'whether within its territory or extraterritorially' that is attributable to a state 'acting separately or jointly with other states or entities' (art. 11). In addition, state responsibility is engaged when states engage in acts or omissions with foreseeable real risk of jeopardising ('nullifying or impairing') the enjoyment of ESC rights beyond their territory (art. 13).

\section{State responsibility for the acts or omissions of IOs in breach of ETOs}

ARIO states that IOs bear responsibility for the breaches of international legal obligations they have undertaken, while member state responsibility for the acts or omissions of IOs has been considered exceptional (Higgins 1995; Ryngaert and Buchanan 2011). Nonetheless, IOs and states may have joint responsibility for the same internationally wrongful act, if responsibility can be attributed to an IO 'in connection with' the act of a state, or if responsibility can be attributed to a state 'in connection with' the act of an IO (ILC 2011b, art. 48, commentary para. 1). As an illustration, in the case European Parliament v. Council of the EU, the Court of Justice of 
the European Union (CJEU) noted that in areas where the EU and its member states had joint competences, the EU and its member states were 'jointly liable' for the obligations assumed by the EU based on the terms of the obligation that had been undertaken (CJEU 1994, para. 29). This responsibility is normally individual but may also be subsidiary when the primary responsibility that has been invoked does not lead to reparation (ILC 2011b, art. 48.2).

When IOs are attributed responsibility for human rights violations, responsibility may also be attributed to member states of the institution for their role in a wrongful act and thus, a breach of their ETOs. There is contention over whether invoking member state responsibility based on membership alone can endanger an IO's independence and effectiveness (as argued by Ryngaert and Buchanan 2011) or not (Stumer 2007). Sarooshi (2005) argues that the extent to which states may be attributed responsibility for the acts of IOs as members depends on the extent of conferred, delegated or transferred powers. For instance, states using IOs as agents retain responsibility for the acts of the agent if they fall within the powers conferred to the agent, but member states which delegate competences to IOs that they also continue to exercise contemporaneously with IOs would not be responsible for the breaches of the IOs (Sarooshi 2005).

The ECtHR has shied away from accepting joint or concurrent responsibility of member states alongside IOs, concerning claims surrounding the actions of the NATO Kosovo Force (KFOR) and of UN Interim Administration Mission in Kosovo (UNMIK), when it declared the cases inadmissible against the respondent states. The Court asserted that the acts in question were attributable to UN, over which it did not have rationae personae jurisdiction (ECtHR 2007). This has led to sidestepping the real issue of how responsibility ought to be attributed in cases where state and IO act and jurisdictions overlap (Sari 2008). In Al-Jedda v. the UK, however, the ECtHR found that responsibility could be attributed both to an IO and its members, in so far as the member states have not completely delegated the authority over the action to the IO (ECtHR 2011a).

The Maastricht Principles, on the other hand, clearly note that states retain responsibility for their conduct, as it affects their human rights obligations both inside and beyond their territory and have an obligation to 'take all reasonable steps to ensure that [an IO to which it transfers competences or in which it participates] acts consistently with [its] international human rights obligations' (art. 15). This duty and the responsibility for its breach exist independently of any obligations and the subsequent responsibility IOs have independently under IL (art. 16). Similarly, General Comment (GC) 16 of the UN Committee on the Rights of the Child notes that states retain their children's rights obligations as members of IOs, including IOs working in development, finance and trade (2013).

\section{State responsibility for the acts or omissions of NSAs}

The issue of state responsibility for the acts and omissions of NSAs is at the core of responsibility for ETOs. This is also the part of the law on responsibility that is the most contested and underdeveloped. Scholars have argued that states should be attributed responsibility for complicity in a corporation's commission of an international crime (Clapham 2004), or for the breach of an extraterritorial due diligence obligation when they fail to oversee and prevent the adverse extraterritorial human rights impacts of their corporations (McCorquodale and Simons 2007). state responsibility according to the Maastricht Principles covers responsibility for conduct (acts or omissions) of NSAs that are 'acting on the instructions or under the directions or control of the state' as organs of the state (art. 12(a)) or those that are 'empowered by the state to exercise elements of governmental authority' when these actors in fact act in that capacity (art. 12(b)). Similarly, the UN Committee on Economic, Social and Cultural Rights' (CESCR) GC 24 on 
state Obligations in the context of business activities recalls that direct international responsibility of states may be invoked in relation to the conduct (acts or omissions) of private actors under three conditions: if that private actor is under its instructions, control or direction, if that private entity is exercising governmental authority, or 'if and to the to the extent that the state party acknowledges and adopts the conduct as its own' (CESCR 2017, para. 11). Beyond those conditions, also enumerated under ARSIWA, state responsibility for the conduct of private actors is not widely recognised.

There are no clear legal frameworks to gauge how international legal responsibility might be attributed directly to NSAs, given the ongoing debate on the nature of their 'duties' under IL. It is also unclear whether NSAs will incur direct legal responsibility under IL for human rights violations, given the contestations over unhelpful parameters, such as international legal personality (Erdem Türkelli 2020). For instance, while the norms of due diligence and remediation continue to become more legalised overtime in the case of business enterprises (Erdem Türkelli 2020), states are likely to be confronted with responsibility for failures to regulate the extraterritorial activities of businesses domiciled or headquartered in their territory. Karavias (2015) suggests that home and host state breaches of due diligence obligations, in regulating corporate conduct extraterritorially or within the state's territory, can be considered a basis for the attribution of responsibility. Similarly, CESCR's GC 24 notes that responsibility for violations of ESC rights is invoked when a state fails to carry out its obligation to protect, by taking all reasonable measures to prevent the violation. Even when the responsibility for the conduct also befalls on other actors, including NSAs, provided that the violation was 'reasonably foreseeable' based on the risks presented by the circumstances surrounding the conduct, not having foreseen the violation does not absolve the state from responsibility (2017, para. 32). GC 24 thus expresses a broad due diligence obligation for state parties in relation to the activities of private entities, including business enterprises. Similar breaches of due diligence obligations may also give rise to responsibility, such as when states fail to take adequate measures to protect individuals by preventing violations of human trafficking by NSAs (Gallagher 2016).

\section{Multiple duty-bearers and shared responsibility}

The enforcement of human rights, through international human rights law, designates the domestic state as the primary human rights duty-bearer in its own territory. For that reason, any consideration of responsibility for violations of ETOs necessitates - at the very least - a consideration of shared responsibility between the domestic state and extraterritorial state(s). More broadly, the violation of ETOs may engage shared responsibility among several states, one or more IOs as well as NSAs.

\section{Attribution of responsibility to multiple duty-bearers}

The attribution of responsibility to multiple duty-bearers under ARSIWA and ARIO is foreseen in cases when more than one state engages in the conduct, causing an internationally wrongful act (art. 15 ARSIWA), or when that conduct is a composite act of an IO and one or more member states (art. 12 ARIO). Of course, scenarios of complicity (or 'aid or assistance') would also necessitate a consideration of the attribution of responsibility to multiple dutybearers. The application of ILC articles to multiple duty-bearers is found to be problematic, in terms of how these norms are interpreted and implemented through various independent responsibility mechanisms (Gallagher 2016). The ILC's frameworks on the law on responsibility do not respond to the real-world situations, where the complexity of governance regimes and 
economic transactions often mean that, multiple duty-bearers are involved in various ways, and to different degrees in a wrongdoing or in multiple wrongdoings that result in human rights violations (Erdem Türkelli 2020).

Nollkaemper argues that causal contributions to an internationally wrongful act could also trigger shared responsibility among various duty-bearers, but while such causal contributions are 'necessary' conditions to responsibility they are not 'sufficient' $(2014$, p. 9). The Guiding Principles on Shared Responsibility in IL, an outcome of the EU-funded SHARES project at the University of Amsterdam, look at attributional aspects of shared responsibility to several international persons (states or IOs) to 'an indivisible injury' based either on 'individual, concurrent or cumulative' contribution (Principle 2.2) where contribution requires a causal relationship (Principle 1(d)) (Nollkaemper et al. 2020). Accordingly, the injury may arise from a single internationally wrongful act (Principle 3) or multiple acts (Principle 4). Reaching 'beyond the scope of the ARSIWA and the ARIO', the Guiding Principles allow for responsibility to be owed to individuals or other persons, not only to other states and IOs (ibid., p. 22).

\section{Distribution of responsibility}

While ARIO and ARSIWA recognise the need to attribute responsibility to multiple dutybearers, they do not set out the parameters of how that responsibility is to be apportioned or distributed. Of course, as a fundamental distinction, responsibility to multiple duty-bearers may be attributed on the basis of independent responsibility of each actor, or on the basis of shared responsibility jointly attributed to duty-bearers.

The Guiding Principles on Shared Responsibility distinguish three types of causal relationship to shared responsibility: individual contribution where the contribution is the cause of the injury itself; concurrent contributions where "each of the contributions could have caused the injury' by themselves; and cumulative contributions where 'conduct of multiple international persons together results in an injury that none could have caused on their own' (Nollkaemper et al. 2020, p. 25). What remains missing are situations where contributions take the form of complicity as well as when the initial act or omission leading to the harm is attributable to one actor but others contribute to the continuation of the harm, or where that breach and the resulting harm are a function of the socioeconomic conditions, to which various actors have contributed as opposed to a single discernible act or omission (Erdem Türkelli 2020).

Theoretically, shared legal responsibility can be distributed on the basis of the strength of primary norms (obligations) incumbent upon the actors, causal relationship (causation), nature and strength of contributions to the harm, the role of relative power wielded over other actors, as well as fairness (Nollkaemper and Jacobs 2015). Yet, in cases necessitating shared responsibility, the rights-holder may not be able to distinctly identify the actor or actors, to whom the acts or omissions resulting in the harm can be traced. The tort law principle of joint and several liability has been suggested as a solution in cases when the different contributions of a diverse set of actors leads to a wrongdoing, including when the shared responsibility of an IO and its member states is engaged (Stumer 2007; Ahlborn 2013). In that scenario, rights-holders would bring the entirety of their claims against one of the duty-bearers, and that duty-bearer would then seek to recover the contribution of other duty-bearers (Stumer 2007). Applying the joint and several liability model to the enforcement of responsibility for breaches of international legal norms in practice would be challenging, because there is no clarity as to how one dutybearer would be able to enforce the distribution of responsibility it has incurred against others (Ahlborn 2013). Without endorsing joint and several liability as it exists in domestic settings, the Guiding Principles on Shared Responsibility also envisage that full reparation be made by 
any of the responsible parties to the injured person(s), without the injured person(s) having to justify the attribution of responsibility to specific parties (Principle 10). The exception is when the contribution to the injury is negligible as not to justify full reparations; in those cases, partial reparations may be sought (Nollkaemper et al. 2020). In line with joint and several liability, a responsible party that has made a full reparation for the injury has a right of recourse against the other responsible parties to share the responsibility (Principle 12).

\section{A way forward based on alternative visions: Polycentric governance of responsibility ${ }^{2}$}

The effective enforcement of responsibility under IL for breaches (including breaches of ETOs) that result from the collective or cumulative actions, or omissions of a number of actors may be difficult, given the limitations of the existing frameworks on international legal responsibility. What we may need to embrace, for the time being, is a polycentric governance of responsibility (Ostrom 2009; Prenkert and Shackelford 2014) that is firmly grounded in a recognition of ETOs but attempts to resolve the question of responsibility in a governance model that includes private, governmental and third-sector venues at the local, national and international levels (as proposed by Keohane and Nye 2000). '[E]xisting [enforcement] landscape for responsibility' for human rights violations is already one based - however imperfectly - on polycentricism (Erdem Türkelli 2020, p. 290), and responsibility for breaches of ETOs would fit squarely within this landscape. The polycentric governance of responsibility for violations of ETOs in particular necessitates a notion of responsibility that transcends the frameworks suggested under the ILC Articles, or those confined to using doctrinal understanding of duty-bearing based on territorial jurisdiction or personhood (Erdem Türkelli 2020). Such conceptualisations may rely on alternative legal visions and inspiration on responsibility from outside of the legal field.

\section{Alternative legal visions}

Alternative and more comprehensive legal visions of legal responsibility, particularly relevant to responsibility for breaches of ETOs also exist. Clapham (2006) explored the notion of 'complementarity' (a physics notion that he applied to human rights responsibility) which asserts that how an event is observed depends as much on the viewing apparatus as the observer. For instance, ' $[t]$ he jurisdictional filter of an international or national court' might end up seeing the responsibility of one state but not of the other actors involved in the wrongdoing (Clapham 2010 , p. 56). Yet, the notion of complementarity allows viewer to identify an actor both as private and public, to see multiple duty-bearers and to discern the wrongdoings leading to multiple breaches of IL (Clapham 2006). Of course, complementarity does not clarify how that responsibility ought to be distributed. In the specific case of ETOs, complementarity allows for extraterritorial states to coexist with the domestic states as well as other potential duty-bearers, such as IOs and NSAs as regards the attribution of responsibility.

Tort law may also provide insights, besides the joint and several liability model, with respect to how responsibility may be distributed from an ETO perspective, particularly in relation to human rights violations. The Principles of European Tort Law (PETL 2005) define causation in a much broader way, noting that it is linked to conduct without which the harm (damage) would not have taken place. PETL also defines 'concurrent causes' of damage, which means that '[i]n case of multiple activities, where each of them alone would have caused the damage at the same time, each activity is regarded as a cause of the victim's damage' (art. 3:102). In addition, when rights-holders (victims) have experienced 'personal injury; or injury to human dignity, 
liberty, or other personal rights', the 'gravity, duration and consequences' of the victim's grievance should be considered in the establishment of non-pecuniary damages as well as possibly, the 'degree of fault' of the tortfeasor under the exceptional circumstances where 'it significantly contributes to the grievance of the victim' (art. 10:301(1) and (2)). Hence, responsibility may be distributed on a differentiated scale, where contributions to the wrongdoing causing more harm or injury may give rise to a bigger share of legal responsibility. From the perspective of ETOs, this would mean that the traditional human rights law tenet that domestic states are the primary duty-bearers as regards human rights in their territory, and thus the primary locus of responsibility may be challenged depending on the specific circumstances of a harm or injury, if, for instance, the action or omission of an extraterritorial state were found to be more significant in causing the harm or injury.

Responsibility for systemic or structural violations of global obligations, such as those linked to global justice and alleviation of poverty, necessitates looking beyond strict and direct causality. In this regard, Salomon's proposal (2007) which links responsibility to failures of acting with adequate due diligence and standards of care is particularly important. Salomon puts forth a framework based on 'common but differentiated responsibilities' based on the 'contribution ... to the emergence of the problem', 'relative power ... manifested as influence over the direction of finance, trade, and development', being in a 'position to assist' and 'benefit[ing] ... from the existing distribution of global wealth and resources' (2007, p. 193 [footnotes omitted]).

Of course, legal responsibility for violations that centres on wrongful conduct, injury and reparations is only a limited part of the broader concept of accountability linked to IL (Brunée 2005). The concept of accountability involves the 'justification of an actor's performance visà-vis others, the assessment or judgment of that performance against certain standards, and the possible imposition of consequences if the actor fails to live up to applicable standards' (Brunée 2005, p. 4 [footnote omitted]). Accountability has preventive and corrective functions, by involving standards, principles and mechanisms applicable to the performance and conduct of actors (OHCHR and Center for Economic and Social Rights 2013). 'Shared accountability', a broader concept than shared responsibility, can respond to circumstances currently situated beyond the scope of existing international legal norms, and hence do not give rise to international responsibility (Nollkaemper and Jacobs 2013). For ETOs, the question of accountability that can be enforced politically and socially is indeed an important one, especially when mechanisms to hold extraterritorial states legally accountable are absent.

\section{Alternative visions from outside of the law}

The question of how 'responsibility' ought to be shared between multiple contributors is not specific to the legal field as such. Philosophy and political theory have also dealt with the question of how responsibility can and should be attributed and distributed for actions or omissions of multiple actors.

Larry May, in Sharing Responsibility, calls for a 'partial rather than full responsibility for participation in a joint venture' which 'divid[es] responsibility for a harm' in contrast to the joint and several liability approach (1992, pp.37-38). May's model foresees the attribution of responsibility not only for an actor's direct contributions to harm but also indirect contributions, for instance when an actor shares attitudes that lead to harmful outcomes which allow for the facilitation of acts that result in harm (1992, p. 37). The model does not restrict responsibility to causal relationships and can thus cover situations where 'all parties played a necessary causal role in the harm, and that no one party played a sufficient role' (May 1992, p. 39). Of course, May's focus is on responsibility for natural persons (individuals) in social interactions rather than responsibility 
of actors that participate in international legal processes. Extrapolating insights from May's concept of shared responsibility, actors participating in international legal processes may be found to share attitudes or perpetuate structures, resulting in harms and should correspondingly incur responsibility. For instance, when private and public actors further agendas that allow unchecked financial and corporate interests to reign over economic and social policies at the expense of public interest, and create conditions that render the violations of ESC rights more likely, these social interactions at the global level may in fact form the basis for shared responsibility. What is important is that May does not see the overall responsibility in relation to a fixed whole, meaning that those in leadership positions being apportioned a higher share of responsibility results in the overall responsibility assigned to the harm increasing and not the share of other actors decreasing. For ETOs, this would mean that those actors exercising more decisive roles having differentiated and higher levels of responsibility.

The late political theorist Iris Marion Young, who based her work on responsibility for global injustices on May's social interaction model of responsibility, distinguished two models of responsibility: the liability model of responsibility and the political model of responsibility. The liability model, which links responsibility to 'guilt or fault for harm' in the form of punishment or compensation is applied to events that have already taken place, based on causal connections to the harm (Young 2004, p. 368). Young, who attempted to devise a theory to respond to the question of who bears responsibility for the labour conditions in sweatshops, noticed that beyond the direct liability of factory owners and managers, those farther away in the upper end of the supply chains from sweatshops were too removed. In the shared responsibility model that she believed was necessary, each actor (an individual person or group of persons like in May's approach) would bear partial personal responsibility 'for outcomes or the risks of harmful outcomes' that result from group action (Young 2004, p. 380). Consequently, Young devised the forward-looking theory of political responsibility for structural injustices to complement the liability model, by focusing on the future action of actors (2006). The model is based on the variables of power ('power or influence over the processes ... produc[ing] the outcomes'), 'relative privilege' held or gained as a result of structural injustice, 'interest' in keeping or changing the existing social structures and 'collective ability' in influencing structures (Young 2006, pp. 127-129). The combination of these variables determines the level of political responsibility of an actor in the global structures of injustice in a given issue area. Using the sweatshop example, Young noted that the workers who have the most interest in challenging the status quo would have the least amount of power, privilege and collective ability, while high street retailers benefitting from the system but also able to recover losses by cancelling orders when economic downturn looms on the horizon (IndustriALL 2020) have the most amount of power, privilege, collective ability but the least amount of interest (2006). Using Young's political responsibility model as complementary to the strictu sensu legal responsibility for ETOs would allow to bypass the limitations of territorial jurisdiction and international legal personality as well as direct causality as required by existing international legal responsibility frameworks (Erdem Türkelli 2020).

\section{A final word}

A polycentric governance framework for responsibility for the breaches of ETOs involves the use of existing legal mechanisms for responsibility such as domestic courts based on civil and criminal law, international and regional courts enforcing IL or human rights law as well as human rights treaty bodies (Erdem Türkelli 2020). Polycentricity also necessitates, where they are found to be lacking, the 'construct[ion]', of 'regulatory and political institutions' that can 


\section{Gamze Erdem Türkelli}

deal with social injustices (Young 2004, p. 388), including violations of specific human rights, or of global human rights obligations. Being able to tackle responsibility for human rights violations through multiple domestic and international venues enables access for rights-holders and facilitates the future development of ETOs, by overcoming constraints linked to territorial conceptions of jurisdiction.

\section{Notes}

1. This chapter draws on my doctoral work, my doctoral dissertation (2017) 'Corporate and Corporatelike Actors and Children's Rights: Obligations and Responsibility in Theory and in Practice' (University of Antwerp, Faculty of Law) and my book (2020) Children's Rights and Business: Governing Obligations and Responsibility, Cambridge University Press.

2. This section draws on Chapter 5 of my book (2020) Children's Rights and Business: Governing Obligations and Responsibility, Cambridge University Press.

\section{References}

Ahlborn, C. (2013) 'To Share or Not to Share? The Allocation of Responsibility between International Organizations and their Member States', SHARES Research Paper 28 Die Friedens-Warte/Journal of International Peace and Organization 88 (3-4), 45-75.

Aust, P.H. (2011) Complicity and the Law of State Responsibility, Cambridge University Press.

Brunnée, J. (2005) 'International Legal Accountability through the Lens of the Law of State Responsibility', Netherlands Yearbook of International Law 36(1), 21-56.

Clapham, A. (2004) 'State Responsibility, Corporate Responsibility, and Complicity in Human Rights Violations' in Bomann-Larsen, L. and Wiggen, O. (eds). Responsibility in World Business: Managing Harmful Side-Effects of Corporate Activity, United Nations University Press.

Clapham, A. (2006) Human Rights Obligations of Non-State Actors, Oxford University Press.

Clapham,A. (2010) 'The Subject of Subjects and the Attribution of Attribution' in Boisson de Chazournes, L. and Kohen, M. (eds). International Law and the Quest for Its Implementation: Liber Amicorum Vera Gowlland-Debbas, Brill Nijhoff.

Committee on Economic, Social and Cultural Rights (CESCR) (2017) GC 24 on State Obligations under the International Covenant on Economic, Social and Cultural Rights in the context of business activities, E/C.12/GC/24.

Committee on the Rights of the Child (CRC) (2013) GC 16 on State obligations regarding the impact of the business sector on children's rights, $\mathrm{CRC} / \mathrm{C} / \mathrm{GC} / 16$.

Court of Justice of the EU (CJEU) (1994) European Parliament v. Council of the European Union (Action for annulment - Act of the Council - Lomé Convention), Case C-316/91.

Erdem Türkelli, G. (2017) Corporate and Corporate-like Actors and Children's Rights: Obligations and Responsibility in Theory and in Practice, University of Antwerp, Faculty of Law (Doctoral Dissertation).

Erdem Türkelli, G. (2020) Children's Rights and Business: Governing Obligations and Responsibility, Cambridge University Press.

European Court of Human Rights (ECtHR) (1996) Loizidou v. Turkey, Application no: 15318/89, Judgment (Merits). (2004) Ilascu et al. v. Moldova and Russia [GC], no. 48787/99, \$ 317, 8 July 2004 (Judgment). (2007) Behrami and Behrami v. France and Saramati v. France, Germany and Norway, Applications no. 71412/01 and 78166/01 (Admissibility Decision). (2011a) Al-Jedda v. the United Kingdom, Application no: 27021/08, Judgment.

(2011b) Al-Skeini and Others v. the United Kingdom, Application no: 55721/07, Judgment.

(2014a) Hassan v. The United Kingdom, Application no: 29750/09, Judgment.

(2014b) Jaloud v. the Netherlands, Application no: 47708/08, Judgment.

European Group on Tort Law (2005) 'Principles of European Tort Law' (PETL). 
Gallagher, A.T. (2016) 'The Practice of Shared Responsibility in Relation to Human Rights and Human Trafficking' in Nollkaemper, A. and Plakokefalos, I. (eds). The Practice of Shared Responsibility in International Law, Cambridge University Press.

Higgins, R. (1995) Legal Consequences for Member States of the Non-fulfilment by International Organizations of Their Obligations toward Third Parties, Session of Lisbonne, Extract from Institute of International Law Yearbook 66-I.

IndustriALL. (2020) 'ACT Brands Commit to Responsible Business Practices in Bangladesh', 31 March 2020, http://www.industriall-union.org/act-brands-commit-to-responsible-business-practices-inbangladesh [accessed 1 September 2020].

Inter-American Commission on Human Rights (IACmHR) (2002) 'What is Terrorism? Report on Terrorism \& Human Rights', OEA/Ser.L/V/II.116 Doc. 5 rev. 1 corr.

Inter-American Court of Human Rights (IACtHR) (1988) Case of Velásquez-Rodríguez v. Honduras, Series C No. 4. Case 7.615, Judgment.

International Court of Justice (ICJ) (2007) Application of the Convention on the Prevention and Punishment of the Crime of Genocide (Bosnia and Herzegovina v. Serbia and Montenegro), Judgment.

International Law Commission (ILC) (2001) 'Articles on the Responsibility of States for Internationally Wrongful Acts (ARSIWA)', Annex to General Assembly resolution 56/83 of 12 December 2001, and corrected by document A/56/49(Vol. I)/Corr.4.

(2011a) 'Articles on the Responsibility of International Organisations' (ARIO), https://legal. un.org/ilc/texts/instruments/english/draft_articles/9_11_2011.pdf (accessed 16 July 2021).

(2011b) 'General Commentary to the DARIO', Draft articles on the responsibility of international organizations, with commentaries, https://legal.un.org/ilc/texts/instruments/english/commentaries/9_11_2011.pdf (accessed 16 July 2021).

Karavias, M. (2015) 'Shared Responsibility and Multinational Enterprises', Netherlands International Law Review 62, 91-117.

Keohane, R.O. and Nye, Jr., J.S. (2000) 'Introduction' in Nye, Jr., J.S. and Donahue, J.D. (eds). Governance in a Globalizing World, Brookings Institution Press.

Lanovoy, V. (2016) Complicity and Its Limits in the Law of International Responsibility, Hart Publishing.

May, L. (1992) Sharing Responsibility, University of Chicago Press.

McCorquodale, R. and Simons, P. (2007) 'Responsibility beyond Borders: State Responsibility for Extraterritorial Violations by Corporations of International Human Rights Law', The Modern Law Review $70(4), 598-625$.

Milanovic, M. (2011) Extraterritorial Application of Human Rights Treaties: Law, Principles, and Policy, Oxford University Press.

Nollkaemper, A. (2014) 'Introduction' in Nollkaemper, A. and Plakokefalos, I (eds), Principles of Shared Responsibility in International Law: An Appraisal of the State of the Art, Cambridge University Press, 2014

Nollkaemper, A. and Jacobs, D. (2013) 'Shared Responsibility in International Law: A Conceptual Framework', Michigan Journal of International Law 34, 359-438.

(2015) 'Introduction: Mapping the Normative Framework for the Distribution of Shared Responsibility' in Nollkaemper, A. and Jacobs, D. (eds). Distribution of Responsibilities in International Law, Cambridge University Press.

Nollkaemper, A. and Plakokefalos, I. (2016) 'Conclusions: Beyond the ILC Legacy' in Nollkaemper, A. and Plakokefalos, I. (eds). The Practice of Shared Responsibility in International Law, Cambridge University Press.

Nollkaemper, A. et al. (2020) 'Guiding Principles on Shared Responsibility in International Law', European Journal of International Law 11(11), 15-72.

Office of the High Commissioner for Human Rights (OHCHR) and Center for Economic and Social Rights (2013) 'Who will be Accountable? Human Rights and the Post-2015 Development Agenda', https://www.ohchr.org/Documents/Publications/WhoWillBeAccountable.pdf (accessed 16 July 2021).

Ostrom, E. (2009) 'A Polycentric Approach for Coping with Climate Change', World Bank Policy Research Working Paper No. 5095, 2-54, https://documents1.worldbank.org/curated/en/480171468315567893/ pdf/WPS5095.pdf (accessed 16 July 2021). 


\section{Gamze Erdem Türkelli}

Prenkert, J.D. and Shackelford, S.J. (2014) 'Business, Human Rights, and the Promise of Polycentricity', Vanderbilt Journal of Transnational Law 47, 451-500.

Ryngaert, C. and Buchanan, H. (2011) 'Member State Responsibility for the Acts of International Organizations', Utrecht Law Review 7(1), 131-146.

Salomon, M.E. (2007) Responsibility for Human Rights:World Poverty and the Development of International Law, Oxford University Press.

Sari, A. (2008) 'Jurisdiction and International Responsibility in Peace Support Operations: The Behrami and Saramati Cases', Human Rights Law Review 8, 151-170.

Sarooshi, D. (2005) International Organizations and Their Exercise of Sovereign Powers, Oxford University Press.

Stumer, A. (2007) 'Liability of Member States for Acts of International Organizations: Reconsidering the Policy Objections', Harvard International Law Journal 48(2), 553-580.

UN Human Rights (HR) Committee (2009) Munaf v. Romania, CCPR/C/96/D/1539/2006.

Young, I.M. (2004) 'Responsibility and Global Labor Justice', The Journal of Political Philosophy 12(4), $365-388$.

(2006) 'Responsibility and Global Justice: A Social Connection Model', Social Philosophy \& Policy Foundation 23(1), 102-130. 